\title{
Does inhaled salbutamol before surfactant therapy have any beneficial effect?
}

\author{
H. Tolga Çelik, Murat Yurdakök, Ayşe Korkmaz, Şule Yiğit \\ Division of Neonatology, Department of Pediatrics, Hacettepe University Faculty of Medicine, Ankara, Turkey. \\ E-mail: htcelik@gmail.com \\ Received: 30th April 2018, Revised: 13th October 2018, Accepted: 23th October 2018
}

SUMMARY: Çelik HT, Yurdakök M, Korkmaz A, Yiğit Ş. Does inhaled salbutamol before surfactant therapy have any beneficial effect? Turk J Pediatr 2018; 60: 669-674.

Beta $(\boldsymbol{\beta})_{2}$ adrenergic receptors are present in alveolar type II cells. Previously, the beneficial effects of inhaled salbutamol treatment on respiratory outcomes were shown in premature infants with transient tachypnea of the newborn. We hypothesized that inhaled salbutamol would increase the effects of surfactant on oxygenation in premature infants with respiratory distress syndrome (RDS). Inhaled salbutamol $(0.15 \mathrm{mg} / \mathrm{kg})$ or normal saline solution $(0.30 \mathrm{ml} /$ $\mathrm{kg}$ ) was administered as a single dose by micropump nebulizer 10 minutes before the first dose of surfactant (Poractant alfa) treatment in 40 infants with gestational ages ranging from 26 to 36 weeks. The effects of salbutamol therapy were evaluated by determining the duration of respiratory support, number of doses of surfactant, respiratory rate, heart rate, fraction of inspired oxygen, and partial pressure of arterial oxygen before and after salbutamol nebulization. No statistically significant difference was detected between the two groups in duration of respiratory support, number of doses of surfactant, respiratory rate, fraction of inspired oxygen, or partial pressure of arterial oxygen. In this study, no significant effect of inhaled salbutamol treatment on the surfactant therapy in premature infants with RDS was detected.

Key words: newborn, neonate, premature, infant, respiratory distress syndrome, RDS, salbutamol, inhaled salbutamol.

Respiratory distress syndrome (RDS) accounts for approximately half of the causes of respiratory distress in newborns of all gestational ages. Especially in premature infants, its incidence increases in conjunction with decreasing gestational age. The development of the exogenous surfactant for treatment of RDS is one of the most important advances in the history of newborn medicine. Although RDSrelated morbidity and mortality have decreased with the usage of surfactant, it remains an issue of importance, since survival rates of very preterm infants have increased. As a result, investigations concerning developments in the efficacy of surfactant therapy continue. ${ }^{1,2}$

It has been demonstrated that inhaled salbutamol treatment improved pulmonary mechanics in ventilated premature infants with respiratory failure, respiratory distress and chronic lung disease. ${ }^{3-6}$ The beneficial effects of inhaled salbutamol treatment on respiratory outcomes in transient tachypnea of the newborn (TTN) have also been shown. ${ }^{7}$ Beta $(\beta)_{2}$ adrenergic receptors are widely distributed in the respiratory tract, and are found not only in airway smooth muscle cells, but also in other cells in the lung, such as epithelial and endothelial cells, alveolar type II cells, and mast cells. Salbutamol is a selective $\beta_{2}$ adrenergic agonist. It promotes the production of intracellular cyclic adenosine monophosphate (cAMP), which enhances the binding of intracellular calcium to the cell membrane. This action decreases the calcium concentration within cells and results in the relaxation of 
smooth muscle and bronchodilation. ${ }^{8,9}$

We hypothesized that inhaled salbutamol would increase the effects of surfactant in premature infants with RDS. Our objective was to investigate whether a single dose of inhaled salbutamol would increase the effects of the surfactant on oxygenation and whether it is safe for use in premature infants with RDS.

\section{Material and Methods}

The study was performed at the Neonatal Intensive Care Unit (NICU) of Hacettepe University Ihsan Dogramaci Children's Hospital, Ankara, Turkey, between October 2010 and January 2012. The infants included in this study were less than 37 weeks' gestational age (range, 26-36 weeks) at birth, and had clinical and radiographic evidence of RDS. Synchronized intermittent mechanical ventilation or noninvasive nasal continuous positive airway pressure was applied in all patients throughout the study period. A total of 40 premature neonates with RDS were randomly allocated in a double-blind placebocontrolled study to receive either inhaled salbutamol $(n=20)$ or an equal volume of normal saline solution placebo $(n=20)$ at the time of diagnosis on the first day of life (Fig. 1). Inhaled salbutamol $(0.15 \mathrm{mg} / \mathrm{kg})$ or normal saline solution $(0.30 \mathrm{ml} / \mathrm{kg})$ was administered as a single dose by micropump nebulizer 10 minutes before the first dose of surfactant (Poractant alfa, $200 \mathrm{mg} / \mathrm{kg}$ ) treatment. Surfactant was given through the intubation cannula in all patients according to the INSURE protocol. Patients with other respiratory disorders (TTN, meconium aspiration, pneumonitis, iatrogenic lung injury, congenital diaphragmatic hernia, air leakages, congenital heart diseases), arrhythmia, chromosomal anomalies, congenital malformations or anomalies, severe hypoxia, suspected or proven sepsis, congenital infections, multiple organ failure syndrome, disseminated intravascular coagulation, inherited metabolic disorders, immune/non-immune hydrops fetalis, twin-totwin transfusion syndrome, congenital tumors, or non-respiratory disorders (hypocalcemia, persistent hypoglycemia, polycythemia) likely to cause respiratory symptoms; newborns with a history of premature rupture of membranes, maternal diabetes, maternal asthma, or maternal

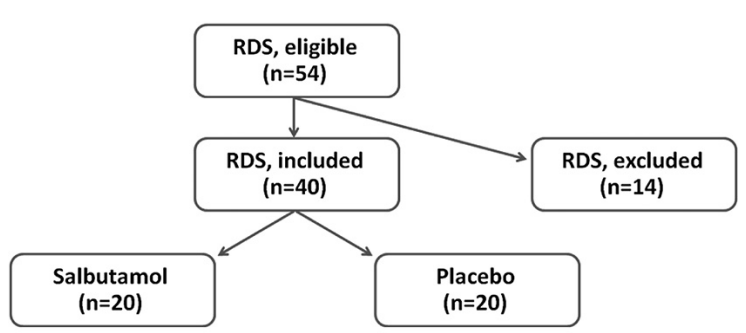

Fig. 1. The flowchart of patients included in the study

bronchodilator drug use; and newborns who died on the first day of life were excluded. Informed consent was obtained from all parents, and the study was approved by the local ethical committee (HEK 07/149-15).

The effects of salbutamol therapy were evaluated by determining the duration of respiratory support, number of doses of surfactant, respiratory rate, heart rate, fraction of inspired oxygen $\left(\mathrm{FiO}_{2}\right), \mathrm{PaO}_{2} / \mathrm{FiO}_{2}$ ratio, MAP (Mean Airway Pressure), OI (Oxygenation Index), oxygen saturation, and partial pressure of arterial oxygen and carbon dioxide before and four hours after salbutamol nebulization.

Preparation and administration of nebulized solutions were performed by a NICU nurse. Parents and investigators remained blinded to the administered medications throughout the study period.

Statistical analyses were performed with PASW Statistics 18 for Windows (Chicago, IL, USA). Normally distributed variables were analyzed with parametric tests (independent or dependent samples t-test). Non-normally distributed variables were analyzed with MannWhitney U test. Fisher's exact test and $\chi^{2}$ tests were used for categorical and qualitative variables. For descriptive statistics, percent, minimum-maximum-median, mean, and standard deviation were used in accordance with the type and distribution of the variable. Values of $\mathrm{p}<0.05$ were considered to be significant.

\section{Results}

There were no differences between the two groups in demographic, maternal and neonatal characteristics (Table I). No statistically significant difference was detected between the two groups in duration of respiratory support, number of doses of surfactant, respiratory rate, heart rate, $\mathrm{FiO}_{2}, \mathrm{PaO}_{2} / \mathrm{FiO}_{2}$ ratio, MAP, 
Table I. The Demographic Characteristics of the Infants and Maternal Features.

\begin{tabular}{|c|c|c|c|}
\hline & $\begin{array}{l}\text { Salbutamol Group } \\
\qquad(\mathrm{n}=20)\end{array}$ & $\begin{array}{l}\text { Control Group } \\
\quad(n=20)\end{array}$ & $P$ value \\
\hline Gender $(\mathrm{F} / \mathrm{M})$ & $13 / 7$ & $9 / 11$ & 0.204 \\
\hline Spontaneous/IVF & $14 / 6$ & $15 / 5$ & 0.723 \\
\hline Gestational age (weeks \pm SD) & $30.4 \pm 2.5$ & $30.5 \pm 1.7$ & 0.883 \\
\hline Birth weight $(g \pm S D)$ & $1378 \pm 499$ & $1356 \pm 379$ & 0.876 \\
\hline AGA/SGA/LGA & $13 / 7 / 0$ & $15 / 5 / 0$ & 0.490 \\
\hline Maternal age $(y)$ & $31.3 \pm 3.3$ & $29.9 \pm 4.1$ & 0.260 \\
\hline Antenatal steroid, n (\%) & $15(75.0 \%)$ & $18(90.0 \%)$ & 0.358 \\
\hline Apgar score $\left(5^{\text {th }} \mathrm{min}\right)^{*}$ & $7.5(5-10)$ & $7.0(6-9)$ & 0.192 \\
\hline Hemoglobin (g/dl) & $16.0 \pm 2.3$ & $16.9 \pm 2.1$ & 0.198 \\
\hline Hematocrit $(\%)$ & $47.3 \pm 6.4$ & $50.2 \pm 6.3$ & 0.157 \\
\hline White blood cell count $\left(/ \mathrm{mm}^{3}\right)$ & $13110 \pm 7444$ & $8890 \pm 4862$ & 0.049 \\
\hline Duration of hospitalization (d)* & $23(7-23)$ & $25(9-49)$ & 0.779 \\
\hline Exitus, n (\%) & $1(5 \%)$ & $2(10 \%)$ & 1.00 \\
\hline $\begin{array}{l}\text { Maternal diseases } \\
\text { Preeclampsia, n (\%) } \\
\text { Thrombophilia, n (\%) } \\
\text { Hypertension, } \mathrm{n}(\%) \\
\text { Goiter (hypothyroisidism), n (\%) }\end{array}$ & $\begin{array}{l}7(35.0 \%) \\
0(0 \%) \\
3(15.0 \%) \\
2(10.0 \%)\end{array}$ & $\begin{array}{ll}3 & (15.0 \%) \\
2 & (10.0 \%) \\
1 & (2.5 \%) \\
2 & (10.0 \%)\end{array}$ & 0.144 \\
\hline $\begin{array}{l}\text { Maternal drug use } \\
\text { Heparin, n (\%) } \\
\alpha-\text { methyl dopa, n (\%) } \\
\text { Ca channel blocker, n (\%) } \\
\text { Aspirin, n (\%) } \\
\mathrm{MgSO}_{4}, \mathrm{n} \mathrm{( \% )}\end{array}$ & $\begin{array}{ll}2 & (5.0 \%) \\
3 & (15.0 \%) \\
3 & (15.0 \%) \\
2 & (10.0 \%) \\
2 & (10.0 \%)\end{array}$ & $\begin{array}{l}2(10.0 \%) \\
1(5.0 \%) \\
3(15.0 \%) \\
0(0 \%) \\
0(0 \%)\end{array}$ & \\
\hline
\end{tabular}

IVF: in vitro fertilization; AGA/SGA/LGA, appropriate-, small-, large- for gestational age;

* median (minimum-maximum value)

OI, oxygen saturation, and partial pressure of arterial oxygen and carbon dioxide before and after salbutamol nebulization. Changes in the heart rate, respiratory rate, and $\mathrm{FiO}_{2}$ over time in the salbutamol and placebo groups were shown on Figure 2. There were also no differences between the salbutamol and control groups with respect to serum $\mathrm{K}^{+}$or glucose levels (Table II).

No adverse effects were observed in our study after single-dose treatment with inhaled salbutamol or saline solution.

\section{Discussion}

Despite the significant advancements in neonatology, RDS is still common and causes significant morbidity and mortality in premature infants. Increasing the effectiveness of the surfactant therapy may decrease the need of mechanical ventilation, related complications and duration of hospitalization of premature infants with RDS. However, thus far, no medicine has been proven to increase the effect of the surfactant.

In this study, we aimed to investigate whether inhaled salbutamol, applied before surfactant therapy, could increase the effect of the surfactant, since its beneficial effects on pulmonary mechanics and respiratory outcomes in premature infants with respiratory failure, respiratory distress, TTN, and especially chronic lung disease have been demonstrated. This is the first study investigating the efficacy of a single dose of inhaled salbutamol treatment on surfactant therapy in premature infants with RDS on the first day of life. In this study, no significant effect of the inhaled salbutamol treatment on the surfactant therapy in premature infants with RDS was detected. Radioligand binding studies on lobectomy specimens have shown $\beta_{2}$-receptor density to 
Table II. The Comparison of Respiratory, Clinical and Laboratory Findings of the Salbutamol and Placebo Groups.

\begin{tabular}{|c|c|c|c|}
\hline & $\begin{array}{l}\text { Salbutamol Group } \\
(n=20)\end{array}$ & $\begin{array}{l}\text { Control } \\
\text { Group } \\
(\mathrm{n}=20)\end{array}$ & $P$ value \\
\hline \multicolumn{4}{|l|}{ Respiratory rate (breaths/min) } \\
\hline Before & $60.9 \pm 9.5$ & $64.5 \pm 8.5$ & .242 \\
\hline After (4th hour) & $58.9 \pm 6.5$ & $59.6 \pm 3.2$ & .667 \\
\hline \multicolumn{4}{|l|}{$\begin{array}{l}P \text { value } \\
\text { Heart rate }\end{array}$} \\
\hline Before & $159.2 \pm 13.2$ & $154.7 \pm 9.3$ & .056 \\
\hline After (4th hour) & $149.5 \pm 11.3$ & $146.6 \pm 8.1$ & .165 \\
\hline \multicolumn{4}{|l|}{${ }_{\mathrm{FiO}}^{P}$ value } \\
\hline $\begin{array}{c}\mathrm{FiO}_{2}(\%) \\
\text { Before }\end{array}$ & $52.5(40-100)$ & $55.0(40-80)$ & .640 \\
\hline After (4th hour) & $30.0(21-40)$ & $27.5(21-30)$ & .134 \\
\hline \multicolumn{4}{|l|}{$\mathrm{O}_{2}^{P}$ saturation $(\%)$} \\
\hline Before & $89.4 \pm 4.3$ & $90.1 \pm 3.4$ & .570 \\
\hline After (4th hour) & $94.2 \pm 2.8$ & $92.9 \pm 2.3$ & .118 \\
\hline \multicolumn{4}{|l|}{$\begin{array}{c}P \text { value } \\
\mathrm{PaO}_{2}(\mathrm{mmHg})\end{array}$} \\
\hline Before & $52.7 \pm 13.6$ & $52.8 \pm 21.6$ & .640 \\
\hline After (4th hour) & $60.1 \pm 13.4$ & $56.8 \pm 21.2$ & .242 \\
\hline \multicolumn{4}{|l|}{$\begin{array}{l}P \text { value } \\
\mathrm{Pa}_{\mathrm{CO} 2}(\mathrm{mmHg})\end{array}$} \\
\hline Before & $48.4 \pm 9.5$ & $46.7 \pm 8.4$ & .557 \\
\hline After (4th hour) & $42.4 \pm 9.4$ & $43.3 \pm 10.1$ & .780 \\
\hline \multicolumn{4}{|l|}{$\begin{array}{l}\mathrm{P} \text { value } \\
\mathrm{PaO}_{2} / \mathrm{FiO}\end{array}$} \\
\hline Before & $0.95 \pm 0.36$ & $1.00 \pm 0.43$ & .744 \\
\hline After (4th hour) & $1.36 \pm 0.48$ & $1.34 \pm 0.54$ & .925 \\
\hline $\begin{array}{l}P \text { value } \\
\text { MAP }\end{array}$ & & & \\
\hline MAP & $7.05 \pm 0.85$ & $6.23 \pm 0.58$ & .211 \\
\hline \multicolumn{3}{|r|}{ 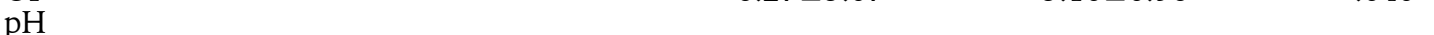 } & .640 \\
\hline Before & $7.26 \pm 0.07$ & $7.28 \pm 0.06$ & .410 \\
\hline After (4th hour) & $7.30 \pm 0.07$ & $7.29 \pm 0.06$ & .341 \\
\hline$P$ value & .048 & .325 & .330 \\
\hline Surfactant doses* & $1(1-5)$ & $2(1-5)$ & .127 \\
\hline \multicolumn{4}{|l|}{ Serum $\mathrm{K}^{+}(\mathrm{mEq} / \mathrm{L})$} \\
\hline Before & $4.1 \pm 0.7$ & $4.0 \pm 0.6$ & .691 \\
\hline After (4th hour) & $3.9 \pm 0.8$ & $4.1 \pm 0.6$ & .489 \\
\hline \multicolumn{4}{|l|}{$\begin{array}{l}P \text { value } \\
\text { Serum glucose }(\mathrm{mg} / \mathrm{dL})\end{array}$} \\
\hline Before & $71.6 \pm 33.4$ & $63.3 \pm 28.1$ & .512 \\
\hline After (4th hour) & $114 \pm 43.7$ & $111.8 \pm 29.7$ & .850 \\
\hline \multicolumn{4}{|l|}{$\begin{array}{l}P \text { value } \\
\text { Duration of respiratory support }\end{array}$} \\
\hline $\begin{array}{l}\text { Duration of respiratory support } \\
\text { MV (h)* }\end{array}$ & $24(0-600)$ & $48(0-480)$ & .383 \\
\hline CPAP $(\mathrm{h}) *$ & $45.5(6-840)$ & $44.0(0-262)$ & .355 \\
\hline Oxygen support $(\mathrm{h})^{*}$ & $24(19-744)$ & $24(0-596)$ & .165 \\
\hline
\end{tabular}

$\mathrm{MV}$, mechanical ventilation; CPAP, continuous positive airway pressure

* median (minimum-maximum value)

increase throughout the respiratory tract, with high levels in the central lung and alveolar region. ${ }^{8}$ Although pulmonary mechanics such as airway pressure and resistance and lung compliance were not evaluated in this study, we suggest that a sufficient amount of the inhaled salbutamol may fail to reach the distal airways of the lungs due to the low pulmonary compliance and high airway pressure caused by RDS.

It has been shown in animal studies that density and affinity of $\beta$ receptors may increase with gestational age. ${ }^{10}$ Therefore, it is possible that early premature infants might have poorer responses to salbutamol than 

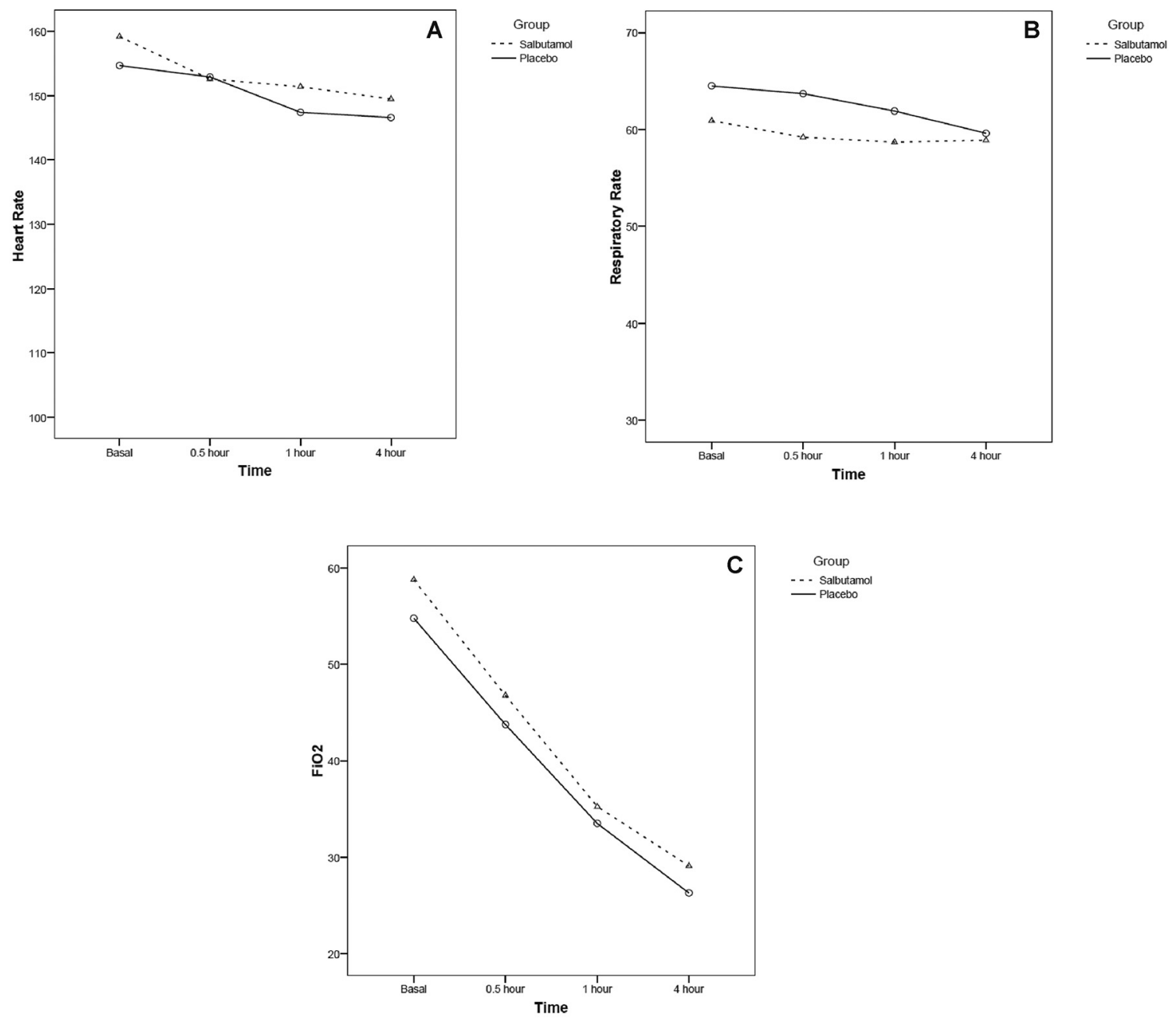

Fig. 2. A, Changes in the heart rate $(p>0.05), \mathbf{B}$, respiratory rate $(p>0.05)$, and $\mathbf{C}, \mathrm{FiO}_{2}(\mathrm{p}>0.05)$ over time in the salbutamol and placebo groups.

term or late preterm infants. Although to our knowledge there are no studies investigating the relationship between gestational age and density and affinity of $\beta_{2}$ receptors within the airways, it may be presumed that premature infants have less $\beta_{2}$ receptors than term infants. We believe that we were unable to obtain an adequate response to salbutamol because our study was performed in premature infants. Another reason may be the administration of surfactant just after the salbutamol treatment because short-acting $\beta_{2}$-agonists, such as salbutamol, are hydrophilic, and access the active site of the $\beta_{2}$-adrenoceptor directly from the extracellular aqueous compartment. ${ }^{8}$ The environment that becomes hydrophobic with the application of the surfactant may have decreased the effect of salbutamol, which remains unabsorbed by bronchial mucosal cells.

In a previous placebo-controlled study, the efficacy of inhaled salbutamol was studied for treatment of TTN in infants with gestational ages of 34-39 weeks. Significant decreases detected in respiratory rate, $\mathrm{FiO}_{2}, \mathrm{TTN}$ clinical score, and duration of hospitalization were significant in the salbutamol group. ${ }^{7}$ Although the gestational age range of our study population differs from this study, we did not find a significant difference in the duration of respiratory support, number of doses of surfactant, respiratory rate, heart rate, $\mathrm{FiO}_{2}$, oxygen saturation, or partial pressure of arterial oxygen and carbon dioxide between the salbutamol and control groups. 
Lee et al. $^{4}$ performed a randomized placebocontrolled study that investigated the bronchodilator aerosol administered by metered dose inhaler and spacer (MDIS) in premature infants with RDS at a postnatal age of 1 week. The infants included in that study $(n=10)$ were less than 34 weeks of gestational age at birth, had RDS and required mechanical ventilation. ${ }^{4}$ They had concluded that single doses of both salbutamol and ipratropium bromide given by MDIS had useful short-term effects in ventilator-dependent neonates with RDS without any clinically significant side effects. ${ }^{4}$ The gestational age range of that study population was similar to that of our study, but doses of salbutamol and route of administration were different. In contrast to that study, we did not find any significant difference in beneficial short-term effects on gas exchange and ventilatory efficiency between the salbutamol and control groups.

We also evaluated the salbutamol group for adverse effects. While serious bronchospasm, arrhythmias, hypokalemia, and hyperglycemia caused by glycogenolysis have been reported in the literature rarely, ${ }^{9}$ no adverse effects were observed in our study after single-dose treatment with inhaled salbutamol or saline solution.

Larger studies are needed to determine whether inhaled salbutamol increases the effects of surfactant in premature infants with RDS.

\section{Acknowledgement}

We thank Anıl Barak from the Department of Biostatistics, Hacettepe University, Faculty of Medicine for statistical analysis.

\section{REFERENCES}

1. Rubaltelli FF, Dani C, Reali MF, et al. Acute neonatal respiratory distress in Italy: A one-year prospective study. Italian Group of Neonatal Pneumology. Acta Paediatr 1998; 87: 1261-1268.

2. Speer CP, Sweet DG, Halliday HL. Surfactant therapy: Past, present and future. Early Hum Dev 2013; 89 (Suppl 1): S22-S24.

3. Ng G, da Silva O, Ohlsson A. Bronchodilators for the prevention and treatment of chronic lung disease in preterm infants. Cochrane Database Syst Rev 2012; 6: CD003214.

4. Lee H, Arnon S, Silverman M. Bronchodilator aerosol administered by metered dose inhaler and spacer in subacute neonatal respiratory distress syndrome. Arch Dis Child Fetal Neonatal Ed 1994; 70: F218-F222.

5. Hilgendorff A, Reiss I, Gortner L, Schüler D, Weber K, Lindemann $\mathrm{H}$. Impact of airway obstruction on lung function in very preterm infants at term. Pediatr Crit Care Med 2008; 9: 629-635.

6. Mhanna MJ, Patel JS, Patel S, Cohn R. The effects of racemic albuterol versus levalbuterol in very low birth weight infants. Pediatr Pulmonol 2009; 44: 778-783.

7. Armangil D, Yurdakök M, Korkmaz A, Yiğit S, Tekinalp G. Inhaled beta-2 agonist salbutamol for the treatment of transient tachypnea of the newborn. J Pediatr 2011; 159: 398-403.e1.

8. Johnson M. Molecular mechanisms of beta(2)-adrenergic receptor function, response, and regulation. J Allergy Clin Immunol 2006; 117: 18-24.

9. Nelson HS. Beta-adrenergic bronchodilators. N Engl J Med 1995; 333: 499-506.

10. Schumacher W, Mirkin BL, Sheppard JR. Biological maturation and beta-adrenergic effectors: Development of beta-adrenergic receptors in rabbit heart. Mol Cell Biochem 1984; 58: 173-181. 